\title{
İnsan İmmün Yetmezlik Virüsü (HIV) Enfeksiyonu Tanısında Enzim 'Immunoassay' (EIA), İmmünoblot ve HIV RNA Polimeraz Zincir Reaksiyonu Test Sonuçlarının Değerlendirilmesi
}

\author{
Evaluation of Enzyme Immunoassay (EIA), Immunoblot and \\ HIV RNA Polymerase Chain Reaction Test Results in the \\ Diagnosis of Human Immunodeficiency Virus (HIV) Infection
}

\author{
Rabia Can SARINOĞLU1 ${ }^{1}$ İmran SAĞLIK², Derya MUTLU ${ }^{3}$, Gözde ÖNGÜT $^{3}$, Dilara iNAN ${ }^{4}$, \\ Dilek ÇOLAK ${ }^{3}$ \\ ${ }^{1}$ T.C. Sağlık Bakanlığı Marmara Üniversitesi İstanbul Pendik Eğitim ve Araştırma Hastanesi, Tıbbi Mikrobiyoloji \\ Bölümü, İstanbul. \\ ${ }^{1}$ T.C. Ministry of Health Marmara University, istanbul Pendik Training and Research Hospital, Department of Medical \\ Microbiology, istanbul, Turkey. \\ 2 Uludağ Üniversitesi Tıp Fakültesi, Tıbbi Mikrobiyoloji Anabilim Dalı, Bursa. \\ 2 Uludağ University Faculty of Medicine, Department of Medical Microbiology, Bursa, Turkey. \\ ${ }^{3}$ Akdeniz Üniversitesi Tıp Fakültesi, Tıbbi Mikrobiyoloji Anabilim Dalı, Antalya. \\ ${ }^{3}$ Akdeniz University Faculty of Medicine, Department of Medical Microbiology, Antalya, Turkey. \\ ${ }^{4}$ Akdeniz Üniversitesi Tıp Fakültesi, Enfeksiyon Hastalıkları ve Klinik Mikrobiyoloji Anabilim Dalı, Antalya. \\ ${ }^{4}$ Akdeniz University Faculty of Medicine, Department of Infectious Diseases and Clinical Microbiology, Antalya, Turkey.
}

\begin{abstract}
Makale Atıf: Sarınoğlu RC, Sağlık i, Mutlu D, Öngüt G, Inan D, Çolak D. Insan immün yetmezlik virüsü (HIV) enfeksiyonu tanısında enzim 'immunoassay' (EIA), immünoblot ve HIV RNA polimeraz zincir reaksiyonu test sonuçlarının değerlendirilmesi. Mikrobiyol Bul 2019;53(4):401-407.
\end{abstract}

Öz

Kazanılmış immün yetmezlik sendromu (AIDS) önemli bir küresel halk sağlığı sorunudur. Her yıl bildirilen HIV/AIDS olgularının sayısı artmakta ve bu durum ülkemiz için önemli bir sağlık sorunu haline gelmektedir. İnsan immün yetmezlik virüsü (HIV) enfeksiyonlarının laboratuvar tanısında ilk basamak olan dördüncü kuşak enzim "immunoassay (EIA)" testinin tekrarlayan şekilde reaktif bulunması halinde doğrulama testi olarak immünoblot (IB), "line immunoassay (LIA)", HIV 1-2 antikor ayırt edici hızlı testler gibi antikora dayalı testler ve enfeksiyonun erken dönemi için HIV RNA saptayan testler kullanılmaktadır. Bu çalışmada, HIV enfeksiyonunun tanısında kullanılan üç farklı yöntemin sonuçlarının birlikte değerlendirilmesi ve yorumlanması amaçlanmıştır. Akdeniz Üniversitesi Hastanesi Merkez Laboratuvarında, Ocak 2010 ve Aralık 2015 tarihleri arasında HIV 1-2 Ab+Ag EIA test sonucu reaktif ya da gri zon olarak saptanan 199 hastaya ait örneklerde HIV 1-2 Ab IB ve kantitatif HIV-1 RNA polimeraz zincir reaksiyonu (PCR) testleri çalışılmışır. Serum örneklerinde HIV 1-2 $\mathrm{Ab}+\mathrm{Ag}$ tayini elektrokemilüminesans EIA yöntemi (Elecsys HIV combi PT test, Roche Diagnostics, Almanya) ile yapılmış, HIV 1-2 IB yönteminde ticari bir kit (INNO-LIA HIV I/II Score, Innogenetics, Belçika) kullanılmışır. HIV-1 RNA varlığı plazma örneklerinde otomatize nükleik asit ekstraksiyonu ve gerçek zamanlı PCR yöntemi (Ampliprep/COBAS Tagman HIV-1 Test, Roche Diagnostics, Almanya) ile araştııımıştır. İstatistiksel analiz için 
İnsan İmmün Yetmezlik Virüsü (HIV) Enfeksiyonu Tanısında Enzim ‘Immunoassay’ (EIA), İmmünoblot ve HIV RNA Polimeraz Zincir Reaksiyonu Test Sonuçlarının Değerlendirilmesi

veriler SPSS'ye kaydedilmiş, Mann-Whitney U testi kullanılmış ve ROC analizi yapılmıştır, $\mathrm{p}<0.05$ değerleri anlamlı kabul edilmiştir. Örneklerin HIV 1-2 Ab+Ag EIA testinin ortanca COI (cut-off indeks) değerleri; HIV 1-2 IB ve HIV-1 RNA testlerinin birlikte pozitif olması durumunda, HIV 1-2 IB ve HIV-1 RNA testlerinin birlikte negatif olması durumuna göre anlamlı olarak daha yüksek çıkmışır [sırasıyla; 394 (aralık: 11.5-2272) ve 1.79 (aralık: 1.01-83.3), $\mathrm{p}<0.001$ ]. HIV 1-2 IB test sonucu greyzon olan bir hasta ve negatif olan iki hastada HIV-1 RNA pozitifliği saptanmıştır (viral yük sırasıyla; > 10.000.000, > 10.000.000 ve 5.040.000 kopya/ ml). HIV 1-2 Ab+Ag ElA COI değerinin, kullandığımız kit için 16.45'ten büyük olmasının HIV enfeksiyonunu göstermede duyarlılı̆ı \%97.6, özgüllüğü \%98.1, pozitif prediktif değeri (PPD) \%97.6 ve negatif prediktif değeri (NPD) \%98.1 olarak hesaplanmıştır ( $r=0.994$, p<0.001). HIV 1-2 Ab+Ag EIA COI değerinin 9.26'dan küçük olmasının ise duyarlılı̆ı \%100, özgüllüğü \%92.5, PPD'si \%91.1 ve NPD'si \%100 olarak bulunmuştur $(\mathrm{p}<0.001)$. HIV 1-2 Ab+Ag EIA test sonucu tekrarlayan reaktif olup; HIV 1-2 IB testi ve HIV-1 RNA testlerinin de pozitif olması HIV enfeksiyonu tanısını koydurmaktadır. Çalışmamızda bu grup hastalarda HIV 1-2 Ab+Ag EIA testinin COI ortanca değeri 394 (aralık: 11.5-2272) çıkmıştır $(p<0.001)$. HIV EIA testi tekrarlayan reaktif ve HIV IB testi gri zon saptanan bir hastada ve negatif saptanan iki hastada (HIV EIA COI değerleri sırasıyla; 265.0, 9.5 ve 131.8) HIV-1 RNA PCR testi ile pozitiflik (HIV-1 RNA sırasıyla; > 10.000.000, 5.040.000 ve > 10.000.000 kopya/ml) saptanmıştır. Bu olgular klinik ve laboratuvar bulguları ile akut HIV enfeksiyonu tanısı almışlardır. Akut HIV enfeksiyonu düşünüldüğünde mutlaka HIV RNA'nın da çalışılması ve tanı algoritmasında yer alması gerekmektedir.

\section{Anahtar kelimeler: HIV EIA; COI; akut HIV enfeksiyonu.}

\section{ABSTRACT}

Acquired Immunodeficiency syndrome (AIDS) is an important global public health issue. Increasing HIV/AIDS cases reported each year has become a serious health problem for our country. The fourth generation enzyme immunoassay (EIA) test is the first step in the laboratory diagnosis of human immunodeficiency virus (HIV) infection. When the EIA test is repeatedly reactive, antibody-based tests such as immuno blot (IB), line immunoassay (LIA), HIV 1-2 antibody differentiation immunoassay, and HIV RNA tests for the early period of infection are used as confirmatory tests. The aim of this study was to evaluate the results of three different methods for the diagnosis of HIV infection. HIV 1-2 IB and quantitative HIV-1 RNA PCR tests were performed in 199 patient samples. These samples were detected as the reactive or gray zone with HIV 1-2 Ab+Ag EIA test between 2010 and 2015 at Akdeniz University Hospital, Microbiology Laboratory. HIV 1-2 Ab+Ag determination in serum samples was performed with the EIA method (Elecsys HIV combi PT test, Roche Diagnostics, Germany). A commercial kit (INNO-LIA HIV I-II Score, Innogenetics, Belgium) was used for HIV 1-2 IB method. The presence of HIV-1 RNA was investigated by automated nucleic acid extraction and real-time PCR method (Ampliprep/COBAS Tagman HIV-1 Test, Roche Diagnostics, Germany) in plasma samples. For statistical analysis, SPSS, Mann Whitney U test was used, ROC analysis was performed and $\mathrm{p}<0.05$ value was considered statistically significant. HIV 1-2 $\mathrm{Ab}+\mathrm{Ag}$ EIA COI (cut-off index) median value was higher with positive HIV 1-2 IB and HIV-1 RNA results than negative HIV 1-2 IB and HIV-1 RNA results. These values were 394 (range: 11.5-2272) and 1.79 (range: $1.01-83.3)$ respectively and this difference was statistically significant $(\mathrm{p}<0.001)$. HIV-1 RNA test results were positive in one patient with gray zone and two patients with negative HIV 1-2 IB result (viral loads were $>10.000 .000,>10.000 .000$ and 5.040.000 copies/ml, respectively). For the kit that we used for HIV 1-2 Ab+Ag EIA COI ratio of $>16.45$ had a sensitivity, specificity, positive predictive value (PPV) and negative predictive value (NPV) of $97.6 \%, 98.1 \%, 97.6 \%$ and $98.1 \%$, respectively for the detection of HIV infection $(r=0.994, p<0.001)$. HIV 1-2 Ab+Ag EIA S/CO ratio of $<9.26$ had a sensitivity, specificity, PPV and NPV of $100 \%, 92.5 \%, 91.1 \%$ and $100 \%(p<0.001)$. HIV infection is diagnosed if HIV $1-2 \mathrm{Ab}+\mathrm{Ag}$ EIA test result is repeatedly reactive and HIV 1-2 IB test and HIV-1 RNA tests are positive. In our study, HIV 1-2 Ab+Ag EIA COI median value was 394 (range: $11.5-2272)$ in this group of patients $(p<0.001)$. HIV-1 RNA PCR test was positive in three patients with $>10.000 .000,5.040 .000$ and $>10.000 .000 \mathrm{copies} / \mathrm{ml}$ whose EIA tests were repeatedly reactive. HIV IB test was detected as the gray zone in one of them and as negative in the remaining two (HIV EIA S/CO values were 265, 9.5 and 131.8, respectively). These patients were diagnosed as acute HIV infection with clinical and laboratory findings. In conclusion, HIV RNA should also be performed and included in the diagnostic algorithm for acute HIV infection.

Keywords: HIV enzyme immunassay; cut off index; acute HIV infection. 


\section{GíRiş}

Kazanılmış immün yetmezlik sendromu (AIDS) önemli bir küresel halk sağlığı sorunu olup, son yıllarda özellikle Dünya Sağlık Örgütü (DSÖ), Hastalık Önleme ve Kontrol Merkezi (CDC) ve Birleşmiş Milletler AIDS Programı (UNAIDS) gibi uluslararası kabul gören kuruluşların çalışmaları ile kontrol altına alınmaya çalışılmaktadır. UNAIDS verilerine göre; 2017 yılında dünya genelinde 36.9 milyon insan immün yetmezlik virüsü (HIV) ile enfekte, 1.8 milyon ise yeni AIDS olgusu bulunmaktadır ${ }^{1}$. Gelecek yıllarda AIDS hastalığının kontrol altına alınması ve hatta sonlandırılması hedeflenmektedir, bunun başarılabilmesi için HIV enfeksiyonlarında erken tanı ve tedavinin sağlanması gerekmektedir. Erken tanı ve tedavi, ölüm oranlarını azaltıp, yaşam beklentisini uzatarak ve bulaş oranlarını etkin bir biçimde düşürerek HIV enfeksiyonunun seyrini olumlu etkilemektedir². Ülkemizde Sağlık Bakanlığı Halk Sağlığı Genel Müdürlüğü, Bulaşıcı Hastalıklar Daire Başkanlığı verilerine göre; ilk olgunun görüldüğü 1985 yılından 31 Aralık 2017 tarihine kadar 16.201'i HIV ile enfekte, 1651'i AIDS olmak üzere toplam 17.884 olgu bildirilmiş olup her yıl bildirilen HIV/AIDS olgularının sayısı artmakta ve bu durum ülkemiz için önemli bir sağlık sorunu haline gelmektedir ${ }^{3}$.

HIV enfeksiyonlarının laboratuvar tanısında ilk basamak olan antikor tarama testlerinde, enzim ile işaretli immünolojik yöntemler yaygın olarak kullanılır. Günümüzde duyarlıı̆ı̆ iyileştirilmiş dördüncü kuşak HIV enzim "immunoassay (EIA)" testlerinde p24 antijeni ile beraber HIV 1-2 IgM ve IgG antikorlarını aynı anda saptayan kombo testler kullanıma girmiştir. Dördüncü kuşak EIA testinin tekrarlayan reaktif bulunması halinde doğrulama testleri olarak antikorların daha özgül saptanmasını sağlayan immünoblot (IB), "line immunoassay (LIA)", indirekt immünofloresan antikor testi, HIV-1/2 antikor ayırt edici hızlı testler gibi antikora dayalı testler ve enfeksiyonun erken dönemi için HIV RNA saptayan testler kullanılmaktadır ${ }^{3-5}$.

HIV/AIDS enfeksiyonunun kontrol altına alınmasında erken tanı için en uygun yaklaşımların belirlenmesinde verilerin paylaşılması önemlidir. Bu çalışma, ülkemizin en yoğun HIV pozitif hasta takip ve tedavisi yapılan merkezlerinden birinde enfeksiyonun tanısında kullanılan üç farklı yöntemin sonuçlarını birlikte değerlendirilerek yorumlanmasını amaçlamaktadır.

\section{GEREÇ ve YÖNTEM}

Bu çalışma, Akdeniz Üniversitesi Tıp Fakültesi Etik Kurulu onayı ile gerçekleştirildi (Tarih: 26 Eylül 2018 ve Karar no: 663).

Akdeniz Üniversitesi Hastanesi Merkez Laboratuvarında, Ocak 2010-Aralık 2015 tarihleri arasında HIV 1-2 Ab+Ag EIA test sonucu tekrarlayan reaktif ya da gri zon olarak saptanan 199 hastaya ait örnekte HIV 1-2 Ab IB ve kantitatif HIV-1 RNA polimeraz zincir reaksiyonu (PCR) testleri çalışıldı. Serum örneklerinde HIV 1-2 Ab+Ag tayini elektrokemilüminesans EIA yöntemi (Elecsys HIV combi PT test, Roche Diagnostics, Almanya) ile gerçekleştirildi ve çıkan sonuçların indeks değeri [COI (cut-off indeks)] kaydedildi. HIV 1-2 Ag+Ab EIA reaktifliği saptanan örnekler aynı yöntem ile iki kez tekrar edildi, üç çalışmadan ikisinde reaktiflik saptanması halinde tekrarlayan reaktivite olarak kaydedildi. HIV 1-2 Ab IB yönteminde HIV-1 
için gp120, gp41, p31, p24 ve p17; HIV-2 için gp36 ve gp105 antijenlerini içeren ticari bir kit (INNO-LIA HIV I/II Score, Innogenetics, Belçika) kullanıldı.

HIV-1 RNA varlığı plazma örneklerinde otomatize nükleik asit ekstraksiyonu ve gerçek zamanlı PCR yöntemi (Ampliprep/COBAS Tagman HIV-1 Test, Roche Diagnostics, Almanya) ile araştırıldı. Tüm testler üretici firmaların önerilerine göre çalışıldı.

\section{İstatistiksel Analiz}

İstatistiksel analiz için veriler SPSS'ye kaydedildi. Mann-Whitney U testi kullanıldı ve ROC analizi yapıldı, $\mathrm{p}<0.05$ değerleri anlamlı kabul edildi.

\section{BULGULAR}

Klinik örneklere ( $n=199$ ) ait HIV 1-2 Ab+Ag EIA, HIV 1-2 IB ve HIV-1 RNA sonuçları Tablo I'de gösterilmiştir.

HIV 1-2 Ab+Ag ElA testi tekrarlayan reaktif olan 196 örnekte HIV 1-2 IB ve HIV-1 RNA sonuçları Tablo II'de gösterilmiştir.

Örneklerin HIV 1-2 Ab+Ag EIA testinin ortanca COI değerleri; HIV 1-2 IB ve HIV-1 RNA testlerinin birlikte pozitif olması durumunda, HIV 1-2 IB ve HIV-1 RNA testlerinin birlikte negatif olması durumuna göre anlamlı olarak daha yüksek saptanmıştır [sırasıyla; 394 (aralık: 11.5-2272) ve 1.79 (aralık: 1.01-83.3), $\mathrm{p}<0.001$ ] (Tablo III).

HIV 1-2 Ab+Ag ElA sonucu tekrarlayan reaktif olan 196 örnek sadece HIV-1 RNA test sonuçlarına göre değerlendirildiğinde HIV-1 RNA pozitif olanlarda COI değeri, negatif olan-

\begin{tabular}{|c|c|c|c|c|c|c|}
\hline & & \multicolumn{3}{|c|}{ HIV 1-2 IB } & \multicolumn{2}{|c|}{ HIV-1 RNA } \\
\hline & & $\begin{array}{l}\text { Pozitif } \\
\text { n (\%) }\end{array}$ & $\begin{array}{c}\text { Gri zon } \\
\text { n (\%) }\end{array}$ & $\begin{array}{c}\text { Negatif } \\
\text { n (\%) }\end{array}$ & $\begin{array}{l}\text { Pozitif } \\
\text { n (\%) }\end{array}$ & $\begin{array}{c}\text { Negatif } \\
\text { n (\%) }\end{array}$ \\
\hline \multirow{2}{*}{$\begin{array}{l}\text { HIV } 1-2 \\
A b+A g \text { EIA }\end{array}$} & Reaktif $(n=196)$ & $87(44.4)$ & $3(1.5)$ & $106(54.0)$ & $89(45.4)$ & $107(54.6)$ \\
\hline & Gri zon $(n=3)$ & $0(0)$ & $0(0)$ & $3(100.0)$ & $0(0)$ & $3(100.0)$ \\
\hline Toplam n (\%) & $199(100.0)$ & $87(43.7)$ & $3(1.5)$ & $109(54.8)$ & $89(44.7)$ & $110(55.3)$ \\
\hline
\end{tabular}

Tablo II. HIV 1-2 Ab+Ag EIA Testi Tekrarlayan Reaktif Olan Örneklerde HIV 1-2 IB ve HIV-1 RNA Sonuçları $(n=196)$

\begin{tabular}{llccc}
\hline & & \multicolumn{3}{c}{ HIV-1 RNA } \\
\cline { 3 - 5 } & & Pozitif $\mathbf{n}(\%)$ & Negatif $\mathbf{~}(\%)$ & Toplam n (\%) \\
\hline HIV 1-2 IB & Pozitif n (\%) & $86(98.8)$ & $1(1.2)$ & $87(100.0)$ \\
& Gri zon n (\%) & $1(33.3)$ & $2(66.7)$ & $3(100.0)$ \\
& Negatif n (\%) & $2(1.9)$ & $104(98.1)$ & $106(100.0)$ \\
& Toplam n (\%) & $89(45.4)$ & $107(54.6)$ & $196(100.0)$ \\
\hline & & & \\
\hline
\end{tabular}




\begin{tabular}{|c|c|c|c|c|}
\hline \multirow[b]{2}{*}{ Durum } & \multirow[b]{2}{*}{ Sayı (n) } & \multicolumn{2}{|c|}{$\mathrm{COI}$} & \multirow[b]{2}{*}{ p } \\
\hline & & Ortanca değeri & Aralık & \\
\hline $\begin{array}{l}\text { HIV 1-2 IB pozitif, } \\
\text { HIV-1 RNA pozitif }\end{array}$ & 86 & 394 & $11.5-2272$ & $<0.001$ \\
\hline $\begin{array}{l}\text { HIV 1-2 IB negatif, } \\
\text { HIV-1 RNA negatif }\end{array}$ & 104 & 1.79 & $1.01-83.3$ & $<0.001$ \\
\hline
\end{tabular}

lardan daha yüksek bulunmuştur [sırasıyla; 389.4 (aralık: 9.5-2272) ve 1.8 (aralık: 1.01270.3), $\mathrm{p}<0.001]$.

HIV-1 RNA pozitif olan 89 hastada HIV-1 RNA ortanca değeri: 156.203 kopya/ml (aralık: 135-> 10.000.000 kopya/ml) olarak bulunmuştur.

HIV 1-2 IB test sonucu gri zon olan bir hasta ve negatif olan iki hastada HIV-1 RNA pozitifliği saptanmıştır (sırasıyla; > 10.000.000, > 10.000.000 ve 5.040.000 kopya/ml). HIV 1-2 Ab+Ag EIA ve HIV 1-2 IB testi pozitif olan bir hastada HIV-1 RNA negatif olarak bulunmuştur. HIV 1-2 IB test sonucu gri zon olan iki hastada HIV-1 RNA sonucu negatif olarak saptanmıştır (Tablo II).

HIV 1-2 Ab+Ag EIA COI değerinin, kullandığımız kit için 16.45'ten büyük olmasının HIV enfeksiyonunu göstermede duyarlılığı \%97.6, özgüllüğü \%98.1, pozitif prediktif değeri (PPD) \%97.6 ve negatif prediktif değeri (NPD) \%98.1 olarak hesaplanmıştır $(r=0.994, p<$ 0.001). HIV 1-2 Ab+Ag EIA COI değerinin, kullandığımız kit için, 9.26'dan küçük olmasının ise duyarlıı̆̆ı \%100, özgüllüğü \%92.5, PPD'si \%91.1 ve NPD'si \%100 olarak bulunmuştur $(p<0.001)$.

\section{TARTIŞMA}

HIV 1-2 Ab+Ag EIA test sonucu tekrarlayan reaktif olup; HIV 1-2 IB testi ve HIV-1 RNA testlerinin de pozitif olması HIV enfeksiyonu tanısını koydurmaktadır. Çalışmamızda bu grup hastalarda HIV 1-2 Ab+Ag EIA testinin COI ortanca değeri 394 (aralık: 11.5-2272) çıkmıştır ( $p<0.001)$. HIV 1-2 Ab+Ag EIA testi tekrarlayan reaktif olup HIV 1-2 IB testi ve HIV-1 RNA testleri negatif olan grupta ise HIV 1-2 Ab+Ag EIA testinin COI ortanca değeri $1.79^{\prime}$ dur (aralık: 1.01-83.3). Blaich ve arkadaşları ${ }^{6}$ çalışmalarında Elecsys sisteminde COI değeri 0.91 ile 4.85 arasında test edilen örneklerin yanlış reaktif, COI değeri en az 84.25 ve üzerinde test edilen örneklerin tamamının gerçek pozitif, ARCHITECT sisteminde ise COI değeri 1.09 ile 12.49 arasında test edilen örneklerin yanlış reaktif, COI değeri $\geq 45.65$ olan örneklerin ise tamamının gerçek pozitif olarak saptandığını bildirmişlerdir. Chacon ve arkadaşlarının çalışmasında ${ }^{7}$ ise, $\mathrm{COI}<10$ olan örnekler yanlış reaktif, $\geq 50$ olan örnekler gerçek pozitif saptanmıştır. Sinyoung ve arkadaşlarının yaptığı çalışmada ${ }^{8}$ ARCHITECT sisteminde yanlış reaktif sonuçların ortalama COI oranı 2.94 (aralık: 1.00-34.59), gerçek pozitif sonuçların ortalama COI değeri ise 385.97 (aralık: 7.28-739.98) olarak saptanmıştır. 
Sonuçlarımız kullandığımız kite özgün olmakla birlikte, yüksek COI değeri ve COI oranı gerçek pozitiflikle ilişkilidir.

Çalışmamızda HIV enfeksiyonu tanısında Elecsys HIV 1-2 Ab+Ag EIA COI değerinin 16.45'ten büyük olmasının HIV enfeksiyonunu göstermede duyarlılığı \%97.6, özgüllüğü \%98.1 olarak bulunmuştur. Chanjuan ve arkadaşları yaptıkları çalışmada ${ }^{9}$, kemilüminesans mikropartikül immünoassay (CMIA) yöntemi ile ROC eğrisi analizi kullanılarak eşik değerini 11.26 (duyarlılığı \%100, özgüllüğü ise \%99.4) olarak saptamışlardır. Sinyoung ve arkadaşları $^{8}$ ise optimal eşik değerini 6.6 olarak aldıklarında duyarlılığı \%100, özgüllüğü ise \%99.99 olarak bulmuşlardır.

Çalışmamızda Elecsys sisteminde çalışırken COI değerinin 9.26'dan küçük olmasının ise duyarlıığı \%100, özgüllüğü \%92.5, PPD'si \%91.1 ve NPD'si \%100 olarak bulunmuştur. Bu hastalarda IB ve HIV-1 RNA testi negatif olup klinik bulgu bulunmamaktadır. Xiaohui ve arkadaşları $^{10}$ dördüncü kuşak elektrokemilüminesan (ChIA) yönteminde COI oranı < 15.0 olan örneklerin tamamının yanlış reaktif olduğunu saptamışlardır. COI oranı $<50$ olan 89 hastadan sadece iki hastada HIV enfeksiyonu olduğunu belirtmişlerdir.

Çalışmamızda hastanemizde takip ve tedavi edilmekte olan HIV pozitif hastalarda HIV-1 RNA ortanca değeri: 156.203 kopya/ml (aralık: 135-> 10.000.000 kopya/ml) olarak bulunmuştur. HIV EIA testi tekrarlayan reaktif ve HIV IB testi gri zon saptanan bir hastada (HIV EIA COI değeri: 265.0) ve HIV IB testi negatif saptanan iki hastada (HIV EIA COI değerleri sırasıyla; 9.5 ve 131.8) HIV-1 RNA PCR testi ile pozitiflik (HIV-1 RNA sırasılla; > 10.000.000 kopya/ml, $5.040 .000 \mathrm{kopya} / \mathrm{ml}$ ve $>10.000 .000 \mathrm{kopya} / \mathrm{ml}$ ) saptanmıştır. Bu olgular klinik ve laboratuvar bulguları ile akut HIV enfeksiyonu tanısı almışlardır. HIV RNA düzeyinin yüksek olması da bunu desteklemektedir. Akut HIV enfeksiyonu düşünüldüğünde IB testi negatif çıkabilmektedir, mutlaka HIV RNA çalışılmalıdır. EIA testleri ile antijen ve antikor saptanmaktadır. Erken dönemde henüz antikorlar oluşmamışken p24 antijeni saptanması ile ElA testi reaktif sonuçlanmaktadır. Bu dönemde IB testi negatif çıkacaktır. Bu nedenle tarama testi olarak dördüncü kuşak EIA testlerin yani kombo testlerin kullanılması durumunda doğrulama testi olarak yalnızca IB testlerinin seçilmesi yetersiz kalmaktadır. Mutlaka HIV RNA'nın da çalışııması ve tanı algoritmasında bulunması gerekmektedir. Dördüncü kuşak EIA testleri ve NAT teknolojisinin kullanılması ile akut HIV enfeksiyonunun saptanmasında artış olduğu bildirilmiştir ${ }^{11-14}$. CDC 2014 yılında erken ya da kronik HIV enfeksiyonundan şüphe edilen hastaların öncelikle FDA onaylı dördüncü kuşak bir kit ile test edilmelerini, tekrarlayan reaktivite saptanan örneklerde IgG temelli bir test ile HIV-1 ve HIV-2 ayırımının yapılmasını, ayırt edici test sonucu negatif ya da belirsiz örneklerde ise erken HIV enfeksiyonunu tanımlamak için HIV-1 RNA çalışımasını önermektedir. 2018 yılında Sağlık Bakanlığı tarafından yayınlanan HIV AIDS tanı rehberinde de bu algoritma esas alınmış ve ülkemizde uygulanmaya başlanmıştır ${ }^{3,15}$.

HIV EIA sonucu tekrarlayan reaktif ve HIV-1 IB testi pozitif olan 87 hastanın birinde (HIV EIA COI değeri: 270.3) HIV-1 RNA PCR sonucu negatif bulunmuştur. Bu hasta HIV pozitif anneden doğan bir bebektir ve anneden transplasental olarak geçen antikorlara bağlı olarak HIV EIA ve HIV IB testlerinde pozitiflik saptandığı düşünülmüştür. Hastanın takibinde altı hafta zidovudin tedavisi verilmiş, birinci ayda, altıncı ayda, sekizinci ayda, bir yaşında, on sekiz aylık iken ve iki yaşında bakılan HIV RNA sonuçları negatif olarak saptanmıştır. 
HIV EIA sonucu reaktif (HIV EIA COI değerleri sırasıyla; 3.5 ve 11.5) ve HIV IB testi gri zon olan iki hastada HIV-1 RNA PCR sonucu negatif bulunmuştur. Bu iki hastada HIV enfeksiyonu kanıtlanamamış ve HIV EIA sonucundaki tekrarlayan reaktivite olması yalancı immün reaksiyon olarak değerlendirilmiştir.

IB ve LIA destekleme testleri, viral antijenlerin her birine özgül antikorların tanımlanmasının sağlaması, yüksek özgüllükleri ve HIV 1-2 ayırımını yapmaları nedeniyle tanıda yararlı testlerdir. Ancak bu testler, dördüncü kuşak EIA testlerine göre enfeksiyonun daha geç döneminde pozitifleşmektedir. Bu nedenle, ElA testlerinde tekrarlayan pozitiflik elde edilen örneklerde, enfeksiyonun erken dönemini saptamak açısından HIV RNA araştııılmalı ve ayrıntılı bir hasta sorgulaması yapılmalıdır. Diğer yandan, rutin laboratuvarlarda HIV reaktivitesi açısından HIV EIA testlerinde elde edilen COI değerlerinin irdelenmesi kesin tanı koymamızı sağlamamakla birlikte, sonuçlardaki öngörümüzü artıracaktır.

\section{ÇIKAR ÇATIŞMASI}

Yazarlar bu makale ile ilgili herhangi bir çıkar çatışması bildirmemişlerdir.

\section{KAYNAKLAR}

1. Documents UNAIDS data 2018. http://www.unaids.org/en/resourches/documents/2018/unaids-data-

2. I.HIV/AIDS Çalıştayı Bildirgesi. 15-16 Ekim 2015, Yeditepe Üniversitesi, İstanbul.

3. Sağlık Bakanlığı Halk Sağlığı genel Müdürlüğü, HIV/AIDS Tanı Klavuzu, Ankara, 2018.

4. Çerçi P, İnkaya AÇ, Alp Ş, Tümer A, Ünal S. HIV/AIDS'li 255 olgunun değerlendirmesi: Hacettepe kohortu. Mikrobiyol Bul 2016;50(1):94-10.

5. Yaşar KK, Kehribar A, Kaşıkçı A, Cebeci N, Pehlivanoğlu F, Şengöz G, et al. HIV/AIDS hastalarına ait HIV RNA sonuçlarının analizi. Med Bul Haseki 2014; 52:80-3.

6. Blaich A, Buser A, Stöckle M, Gehringer C, Hirsch HH, Battegay M, et al. Specificity of two HIV screening tests detecting simultaneously HIV-1 p24 antigen and antibodies to HIV-1 and -2. J Virol Methods 2017;149:143-6.

7. Chacon L, Mateos ML, Holguin A. Relevance of cutoff on a $4^{\text {th }}$ generation ELISA performance in the false positive rate during HIV diagnostic in a low HIV prevalence setting. J Clin Virol 2017;92:11-3.

8. Kim S, Lee JH, Choi JY, Kim JM, Kim HS. False-positive rate of a "fourth-generation" HIV antigen/antibody combination assay in an area of low HIV prevalence. Clin Vaccine Immunol 2010;17(10):1642-4.

9. Cui C, Liu P, Feng Z, Xin R, Yan C, Li Z. Evaluation of the clinical effectiveness of HIV antigen/antibody screening using a chemiluminescence microparticle immunoassay. J Virol Methods 2015;214:33-6.

10. Bi X, Ning H, Wang T, Li D, Liu Y, Yang T, et al. Comparative performance of electrochemiluminescence immunoassay and EIA for HIV screening in a multiethnic region of China. PLoS ONE 2012;7(10):e48162.

11. Rosenberg NE, Pilcher CD, Busch MP, Cohen MS. How can we better identify early HIV infections? Curr Opin HIV AIDS 2015;10(1):61-8.

12. Pilcher $C D$, Fiscus $S A$, Nguyen TQ, Foust $E$, Wolf $L$, Williams $D$, et al. Detection of acute infections during HIV testing in North Carolina. N Engl J Med 2005;352:1873-83.

13. Patel $P$, Klausner JD, Bacon OM, et al. Detection of acute HIV infections in high-risk patients in California. J Acquir Immune Defic Syndr 2006;42:75-9.

14. Soylar M, Altuğlu i, Sertöz R, Gökengin D. Erken dönem HIV enfeksiyonunda line immunoassay testinin yeri: Tanısal bir olgu. Mikrobiyol Bul 2013;47(3):567-9.

15. Centers for Disease Control and Prevention. Laboratory testing for the diagnosis of HIV infection: updated recommendations; 27 June 2014. https://stacks.cdc.gov/view/cdc/23447. 